\title{
Introduction to the Special Issue on Crime and Criminal Justice in Europe
}

\author{
Marcelo F. Aebi ${ }^{1}$ (D) - Jörg-Martin Jehle ${ }^{2}$
}

Published online: 17 March 2018

(C) Springer Science+Business Media B.V., part of Springer Nature 2018

Besides crime surveys, official data on crime and criminal justice are essential both for criminology and criminal policy. The number of offenses, prosecutions, convictions or prisoners gathered through crime and criminal justice statistics and the trends shown by these indicators provide valuable information for policy makers to assess and improve the existing criminal justice system (Aebi 2004; Aebi and Linde 2012; Jehle 2000, 2013). A broader look beyond the national level offers new perspectives: This is not only true for the introduction of new kinds of sanctions and measures or crime prevention, but also for the structure and organization of criminal justice authorities. Methodological issues related to the evaluation of criminal justice statistics, however, become more complex when comparing these data on an international level. Such an analysis has to consider legal and statistical differences between the criminal justice systems and their potential impacts on data availability and data comparability (Harrendorf 2012).

This issue deals with international comparisons within Europe. The various articles refer to the European Sourcebook of Crime and Criminal Justice Statistics as the main data source. This Sourcebook is a comparative data collection covering all stages of the criminal proceedings. Its first edition was published in 1999 and it included data from 1990 to 1996. It was continued by follow-up publications in the years 2003, 2006, 2010 and the 5th edition in 2014 (Aebi et al. 2014). ${ }^{1}$ The next data collection wave, covering the years 2012 to 2016, will be carried out in 2018. The approach of the European Sourcebook is not limited to contrasting figures from national criminal justice statistics: The data collection is complemented by a

${ }^{1}$ For further information see: www.unil.ch/europeansourcebook.

Marcelo F. Aebi

Marcelo.Aebi@unil.ch

Jörg-Martin Jehle

jjehle@gwdg.de

1 School of Criminal Sciences, University of Lausanne, UNIL - ESC - Sorge - BCH, CH-1015 Lausanne, Switzerland

2 Institute of Criminal Law and Justice, Georg-August-Universität Göttingen, Platz der Göttinger Sieben 6, 37073 Göttingen, Germany 
comprehensive set of metadata including definitions of legal terms (e.g. aggravated assault) and details on the counting rules applied by each country when introducing the data in their national crime and criminal justice statistics (Aebi 2010). In this way, data comparability can be improved and deviations from standard definitions and data collection methods become visible. Figures and metadata are collected via a European-wide ${ }^{2}$ network of national correspondents, who are experts in the field of crime indicators.

The European Sourcebook data collection covers the police and the prosecution level, conviction, prison and probation statistics, as well as information on national victimization surveys. The articles in this issue illustrate the diversity of possible analyses based on figures from the European Sourcebook. While all of these five papers refer to the 5th edition, each one features a different focus, such as attrition, trends in police recorded crimes, juvenile criminal justice systems, community sanctions and measures and homicide offenses.

As a starting point, Stefan Harrendorf focuses on attrition processes in three European regions (northern/western, southern and central/eastern Europe). His article addresses different stages of the criminal proceedings, based on data from the European Sourcebook: Figures on offenses, suspects and convicts are combined to calculate offender ratios and conviction ratios. Similarities and differences of the attrition patterns between the European regions are highlighted and evaluated. This comparative approach reveals that conviction ratios differ widely, while surprising similarities regarding the offender ratios between the clustered groups of countries can be found. These comprehensive analyses of the attrition process are complemented by (and correlated with) measurements of the quantitative and qualitative performance of European criminal justice systems, such as the Police Performance Index.

The second article of this issue continues the analysis of European Sourcebook data on the police level. Beata Gruszczyńska and Markku Heiskanen shed light on the trends in police recorded offenses from 2000 to 2011. Crime trends for homicide, assault, rape, burglary, car theft, robbery and drug offenses are not only calculated for three different groups of European countries and for the total, but also contrasted between individual countries. The results show a decrease of homicide rates in many criminal justice systems, while an increase of assault and rape can often be observed. Property crime rates (such as car theft and domestic burglary) have continued to decrease during the first decade of the twenty-first century, which might be caused by an upturn and improvement of technical and electronic security precautions.

Claudia Campistol and Marcelo F. Aebi evaluate data availability and comparability regarding juvenile criminal justice statistics in 45 European countries based on data from the European Sourcebook. Their article addresses different stages of the criminal proceedings including the police level, figures for the prosecution and the conviction stage, as well as prison and probation statistics. The authors illustrate the challenges of such a comparative data collection with a focus on juvenile delinquency: In many European countries, (separate) figures for minors are not available and statistical and legal differences can be observed. To put it in a nutshell, European juvenile criminal justice statistics show a lot of room for improvement. The enhancement of data availability and comparability in this field is an important task, as criminologists, practitioners and criminal policy makers depend on reliable

\footnotetext{
${ }^{2}$ The European Sourcebook study aims at collecting data for all countries of the Council of Europe, except microstates (Andorra, Liechtenstein, Monaco, San Marino).
} 
figures. Juvenile criminal law has occasionally played a pioneering role in introducing new non-custodial forms of sanctioning.

This links up to the following paper in which Jörg-Martin Jehle and Nina Palmowski conduct an empirical analysis of the implementation of sanctions and measures served in the community. A special focus of the 5th edition was set on community sanctions and measures and on the structure, organization and work of probation agencies. Detailed questions on these subjects were elaborated via a preparatory methodological study examining the different concepts and data availability in this field. ${ }^{3}$ The article addresses different forms of two specific measures (supervision and community service) by an indepth analysis of their application and duration in different stages of the criminal justice process as well as their outcome. Calculations are carried out for clustered groups of European countries and for the total. The results indicate that the quantitative importance of certain forms of these measures has risen, but the amount differs within Europe. The same is true for the success of supervision and community service, as different percentages of revocations and completions can be observed for the clustered groups of countries.

In conclusion, the paper of Antonia Linde draws attention to a specific subject. Using the example of Germany (1977-2011), the article examines whether improvements in medical resources have an impact on homicide trends. For this purpose, the study combines data from the European Sourcebook with figures from Interpol's International Crime Statistics as well as information on medical resources, mortality and life expectancy given by the World Health Organization. The results show a decrease in the rate of completed homicides as well as roadtraffic deaths on the one hand and an improvement of healthcare on the other. At the same time, increasing rates of attempted homicides and of aggravated assaults can be observed. This corroborates the hypothesis that medical improvements lead to a decrease of completed homicides.

As a whole, this issue shows the fruitfulness of research approaches based on data from the European Sourcebook of Crime and Criminal Justice Statistics. While a few aspects (such as the outcome of supervision and community service) have been newly introduced in the recent 5 th edition of this study, many others (such as police recorded offenses or conviction statistics) have already been part of former editions. Consequently, it is possible to observe the evolution of the latter over a longer time-span and trends become visible. Similarities and differences of criminal justice systems across Europe can only be assessed validly if the comparability of the data is assured. Otherwise, figures could be misleading and could not serve as a reliable basis for criminal policy decisions. The articles in this issue demonstrate that the approach of the European Sourcebook is promising, because it allows a detailed look at different stages of the criminal proceedings and problems of data comparability can be minimized - or at least identified - with the expertise of the national correspondents and the differentiated accompanying metadata designed by the experts of the European Sourcebook Group. ${ }^{4}$ Last but not least, the analyses carried out in this issue also draw attention to the need of essential improvements in the data collected in national criminal justice statistics, as

\footnotetext{
${ }^{3}$ Developing a Methodology to Collect Data on Community Sanctions and Measures and Attrition Rates in Europe (DECODEUR). This project was funded by the European Commission (under the ISEC programme) and was carried out in cooperation with experts from the Confederation of European Probation (CEP).

${ }^{4}$ The European Sourcebook Group is a Working Group of the European Society of Criminology, see http://www. esc-eurocrim.org/index.php/activities/working-groups/46-european-sourcebook-group.
} 
reliable figures are a necessary condition for well-founded comparisons at the European level.

\section{References}

Aebi, M. F. (2004). Crime trends in Western Europe from 1990 to 2000. European Journal on Criminal Policy and Research, 10(2-3), 163-186.

Aebi, M. F. (2010). Methodological Issues in the Comparison of Police-Recorded Crime Rates. In S.G. Shoham, P. Knepper \& M. Kett (Eds.). International Handbook of Criminology (pp. 211-227). Boca Raton: CRC Press: Taylor \& Francis Group.

Aebi, M. F., \& Linde, A. (2012). Crime trends in Western Europe according to official statistics from 1990 to 2007. In J. Van Dijk, A. Tseloni, \& G. Farrell (Eds.), The international crime drop: new directions in research (pp. 37-75). New York, Houndmills: Palgrave Macmillan.

Aebi, M. F., Akdeniz, G., Barclay, G., Campistol, C., Caneppele, S., Gruszczynska, B., Harrendorf, S., Heiskanen, M., Hysi, V., Jehle, J.-M., et al. (2014). European sourcebook of crime and criminal justice statistics - 2014 (5th ed.). Helsinki: HEUNI.

Harrendorf, S. (2012). Offence definitions in the European sourcebook of crime and criminal justice statistics and their influence on data quality and comparability. European Journal on Criminal Policy and Research, $18(1), 23-53$.

Jehle, J.-M. (2000). Prosecution in Europe: varying structures, convergent trends. European Journal on Criminal Policy and Research, 8(1), 27-42.

Jehle, J.-M. (2013). Crime and criminal justice in Europe, the approach of the European sourcebook. In A. Kuhn, C. Schwarzenegger, P. Margot, A. Donatsch, M. F. Aebi, \& D. Jositsch (Eds.), Criminology, criminal policy and criminal law in an international perspective: essays in honour of Martin Killias (pp. 191-206). Bern: Stämpfli. 